\title{
Environmental Effects on the Performance of Polycrystalline Silicon Solar Cells under Long-Term Outdoor Exposure in Taiyuan, China
}

\author{
Kashif Ali, Yanbing Jia, Muhammad Abbas*, Syed Arslan Bukhari \\ 79 West Yingze Street, Taiyuan University of Technology, Taiyuan, China \\ Email: *Abbas9t2@yahoo.com, *Abbas@link.tyut.edu.cn
}

How to cite this paper: Ali, K., Jia, Y.B., Abbas, M. and Bukhari, S.A. (2019) Environmental Effects on the Performance of Polycrystalline Silicon Solar Cells under Long-Term Outdoor Exposure in Taiyuan, China. Journal of Power and Energy Engineering, 7, 15-27.

https://doi.org/10.4236/jpee.2019.711002

Received: September 24, 2019

Accepted: November 9, 2019

Published: November 12, 2019

Copyright $\odot 2019$ by author(s) and Scientific Research Publishing Inc. This work is licensed under the Creative Commons Attribution International License (CC BY 4.0).

http://creativecommons.org/licenses/by/4.0/

(c) $\underset{\mathrm{EY}}{\mathrm{EY}}$ Open Access

\begin{abstract}
Environmental conditions such as wind, temperature and humidity affect the amount of solar irradiance received by the photovoltaic (PV) cells and thus have a significant effect on the PV output efficiency. This paper aims to analyze the power efficiency of Polycrystalline Silicon solar cells under China's weather considering these environmental conditions. Performance of the Polycrystalline solar panel is analyzed through eight months of data emphasizing the maximum, average and minimum temperature acquired from a solar power plant installed at Taiyuan University of technology, China consisting of $78 \mathrm{PV}$ panels with a total rated capacity of $20 \mathrm{KW}$ and average module efficiency of $16.56 \%$ at an ambient temperature of $25^{\circ}$. The results of our practical investigations show that polycrystalline solar cells in October yield the best monthly average efficiency of $35.6 \%$ at an average temperature and humidity level of $14^{\circ} \mathrm{C}$ and $44 \%$. In comparison to a maximum temperature of $27^{\circ} \mathrm{C}$ and humidity of $66 \%$ in summer, the efficiency is found to drop by $5 \%$. Also, the power produced in winter at minimum temperature and the efficiency showed a decline of $15 \%$ compared to that of October. Consequently, this investigation leads to a conclusion that the increase in temperature and humidity together is found to have a negative effect on the efficiency whereas the increase in irradiance and wind speed showed an improvement in the output power of the polycrystalline solar cells.
\end{abstract}

\section{Keywords}

Efficiency, Polycrystalline, Photovoltaics, Weather Effects 


\section{Introduction}

China firstly installed PV module in 1999 and until now China is the world's largest market for solar energy. In 2017, according to the national development and reform commission of China, China was the first country to achieve 100 GW of cumulative installed PV capacity and as of now it surpassed $180 \mathrm{GW}$ and the goal is to reach $1300 \mathrm{GW}$ by the end of 2050 . Since solar energy is growing very fast, the reliability and weather effects on PV modules are of high interest to manufacturers and all other related beneficiaries [1].

To investigate the effects of weather and/or environmental conditions, there are many studies about weather effects on PV modules at a particular geographic location. For example, high ambient temperature reduces the band gap of semiconductors consequently leading to a reduction in open circuit voltage and output power [2]. Also, it is found out that low temperature leads to interconnect breakage of PV module [3] [4] and [5] has found 5\% of power losses during the winter season in Leganes Madrid.

Moreover, to analyze the effect of humidity and wind speed, a power loss of $43 \%$ was noted in the output of PV panels due to high humidity effect in Surabaya, Indonesia [5]. Further, the wind movement causes large interchange circulation between the temperature of the PV plate and the temperature of surroundings due to convection heat transfer because of which the temperature reduces and the output of PV panels increases [6]. Also, it is discovered in [7] that all type of PV modules in Malaysia yields less than $20 \%$ of output efficiency during heavy clouds and high wind speed. It is concluded in [8] [9] that the low amount of radiation cannot provide enough solar energy to activate short circuit current and voltage. Moreover, water vapors reduce the light transmission of solar panels due to the scattering of light.

In the view of all these studies, our goal here is to provide an overall picture of the direct effects of environmental conditions, such as humidity, wind speed, temperature and solar irradiance on polycrystalline solar cells installed in the Taiyuan city of China where the weather changes dramatically and the temperature varies between $-25^{\circ} \mathrm{C}$ to $35^{\circ} \mathrm{C}$. For this purpose, we analyse eight months of data emphasizing the maximum, average and minimum temperature acquired from the investigated solar power plant through power monitoring module (AP2008-9C).

\section{Monitoring Setup}

To investigate the effects of different weather conditions of a $20 \mathrm{KW}$ solar panel installed on the roof of Taiyuan University of technology during summer with maximum temperature and in winter with minimum temperature, a reading data of every 5 minutes for the duration of eight months collected through the power monitoring module (AP2008-9C) shown in Figure 1 and weather conditions monitored by environment monitoring setup (PC 6) shown in Figure 2.

According to the overall design of the Microgrid experimental system, the to- 
tal installed rated capacity of the project is $20 \mathrm{~kW}$. The components are divided into 13 sets of strings placed on the galvanized steel bracket with south facing at a 25-degree angle shown in Figure 3. Each string has a rated maximum power of $270 \mathrm{~W}$, a rated voltage $\mathrm{V}_{\mathrm{OC}}$ of about $38.10 \mathrm{~V}$ and a rated current $\mathrm{I}_{\mathrm{SC}}$ of about 9.45 A. The Grid-connected inverter (SUN2000-33KTL) has a maximum input DC power of 33,800 $\mathrm{W}$ and a maximum input voltage of $1000 \mathrm{~V}$.

The whole output rated power the considered solar plant is $30,000 \mathrm{~W}$, maximum viewing power $3300 \mathrm{VA}$, maximum active power (at unity power factor) $3300 \mathrm{~W}$, rated output voltage $380 \mathrm{~V}$, output frequency $50 \mathrm{~Hz}$, maximum output current $48 \mathrm{~A}$ and maximum total harmonic distortion 3\%. The Rated Parameters given by the manufacturer on the nameplate of the module are given in Table 1.

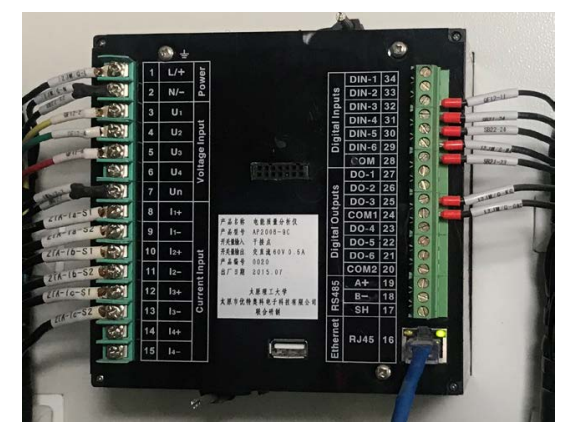

Figure 1. Power monitoring module (AP2008-9C).

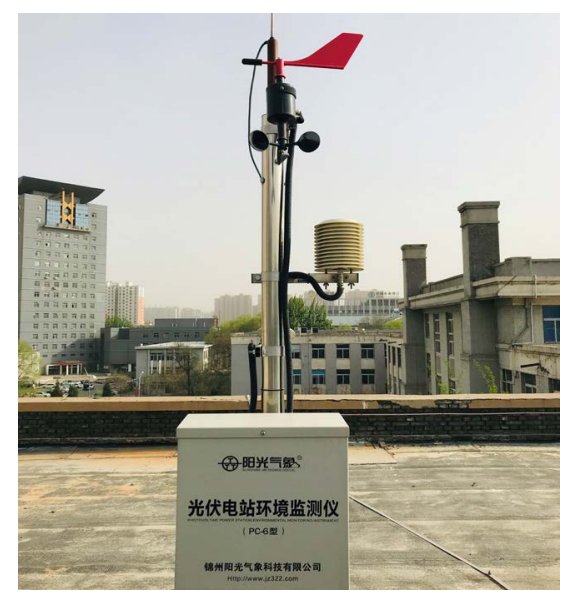

Figure 2. Photovoltaic power station environment monitoring setup (PC 6).

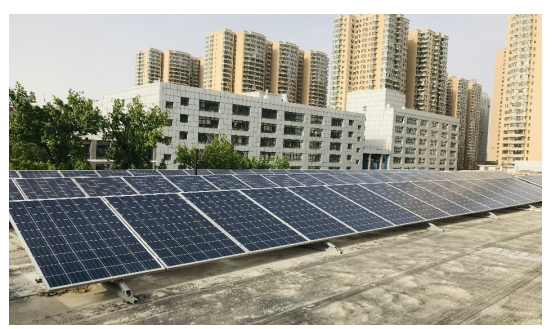

Figure 3. Outdoor PV module performance testing setup at taiyuan university of technology, China. 
Table 1. Technical rated data of the module under investigation.

\begin{tabular}{cccc}
\hline Parameter & Symbol & Unit & Value \\
\hline Maximum Power & $\mathrm{P}_{\mathrm{MAX}}$ & Watt $(\mathrm{W})$ & 270 \\
Maximum Current & $\mathrm{I}_{\mathrm{MAX}}$ & Ampere $(\mathrm{A})$ & 8.77 \\
Maximum Voltage & $\mathrm{V}_{\mathrm{MAX}}$ & Volt $(\mathrm{V})$ & 30.80 \\
Short Circuit Current & $\mathrm{I}_{\mathrm{SC}}$ & Ampere $(\mathrm{A})$ & 9.45 \\
Open Circuit Voltage & $\mathrm{V}_{\mathrm{OC}}$ & Volt $(\mathrm{V})$ & 38.10 \\
Average Temperature & ${ }^{\circ} \mathrm{C}$ & Centigrade $\left({ }^{\circ} \mathrm{C}\right)$ & 25 \\
Module Area & $\mathrm{A}$ & $\mathrm{M}^{2}$ & 1.63 \\
Fill Factor & $\mathrm{FF}$ & & 0.75 \\
Average Module Efficiency & $\mathrm{AME}$ & Percentage $(\%)$ & 16.56 \\
\hline
\end{tabular}

\section{Methodology}

The investigation is carried out under different weather conditions at high and low temperatures in open circumstances and also a range of different parameters were analyzed. All the data of atmospheric temperature, PV panels temperature, wind speed, humidity, irradiance, output power and efficiency of PV panels were monitored through eight months at the interval of every 5 minutes and then the average daily data and average monthly data were calculated.

\section{Efficiency}

In this study, the efficiency of the solar setup is used to define the performance of the module as [7]

$$
\begin{gathered}
\eta=\left(\frac{P_{\text {out }}}{P_{\text {inp }}}\right) \times 100 \\
\eta=\left(P_{\max } / E A_{c}\right) \times 100
\end{gathered}
$$

where, $\eta$ is the maximum rated efficiency, $P_{\max }$ is the maximum power output, $E$ is the maximum irradiance measured in $\mathrm{W} / \mathrm{m}^{2}$ and $A_{c}$ is the area of the module.

where the final efficiency per day is important to find out the performance of the working module

$$
A M E=F F \times\left(V_{A V E} \times I_{A V E}\right) /\left(A_{c} \times G\right)
$$

where $A M E$ stands for the average module efficiency, $V_{A V E}$ and $I_{A V E}$ are average voltage and current, $G$ is the solar irradiance and $F F$ stands for fill factor. This value of efficiency is not constant it depends upon the solar irradiance, time and temperature of the module. Also, the fill factor is given by [7]

$$
F F=P_{\text {max }} / V_{O C} \times I_{S C}
$$

where, $V_{O C}$ and $I_{S C}$ are the open circuit output voltage and short circuit current of the module. The performance of each solar module cannot be obtained only by looking at the output of the module. That's why the power output effi- 
ciency is taken under consideration as a performance index which is obtained from output power. With the output efficiency, we can show how much power is generated at a specific time of the installed capacity of the module.

\section{Data and Results}

To understand all the aspects of weather effects on Polycrystalline module, different methods were used to extract trends for efficiency percentage, output power and fill factor. The performance of Polycrystalline solar cells yields monthly average efficiency at best because of low humidity, temperature and maximum sun time. Whereas, the efficiency found to drop significantly because of high humidity and rising temperature of the module. In winter with low temperature, the output power and efficiency decrease gradually with decreasing temperature mainly due to the short time of sun and weaker sun rays in comparison to that of summer.

Weather conditions of summer help solar panels because mostly in Taiyuan temperature stays between $25^{\circ} \mathrm{C}$ and $35^{\circ} \mathrm{C}$, which is the possible best temperature for the solar panel. According to [7], Countries where in summer the temperature goes past from $35^{\circ} \mathrm{C}$, it decreases the efficiency by approximately $0.52 \%$ with every increasing temperature of $1^{\circ} \mathrm{C}$.

The highest and the lowest temperature effect, humidity, wind, and irradiance effect on the same PV panels at a fixed angle and same direction in the outdoor environment are found out as:

\subsection{Analysis for June, 2018}

In June, the timing of sun in Taiyuan is around 14 hours and the temperature remains between $25^{\circ} \mathrm{C}$ and $30^{\circ} \mathrm{C}$ which is very fruitful temperature for solar panels mostly when the sky remains clear. The solar power output highly depends upon the solar radiations which are connected to the temperature and humidity as shown in Figure 4 and Figure 5 that the output increases with the increasing radiance level. The maximum output we got in June is when the average temperature of the day was $25^{\circ} \mathrm{C}$ average humidity $30 \%$ wind speed was $1.84 \mathrm{~km} / \mathrm{h}$ shown in Figure 5.

\subsection{Analysis for July, 2018}

In July, the average temperature remains between $27^{\circ} \mathrm{C}$ to $30^{\circ} \mathrm{C}$ and the module average temperature touches $35^{\circ} \mathrm{C}$ with maximum average irradiance level in a day up to $520 \mathrm{KW} / \mathrm{m}^{2}$ as shown in Figure 6 . The maximum average output received in a day was $9.3 \mathrm{KW}$ as shown in Figure 7 when the irradiance level was maximum at $509 \mathrm{KW} / \mathrm{m}^{2}$ with an average temperature of the day $28^{\circ} \mathrm{C}$, module temperature $33^{\circ} \mathrm{C}$ and the lowest humidity level of the month at $50 \%$.

The average efficiency for the month of July is $30 \%$. In comparison with that of June, the efficiency decreases slightly by $1 \%$ because of the high humidity, lower wind speed, and mostly cloudy weather even at a higher temperature than June. 


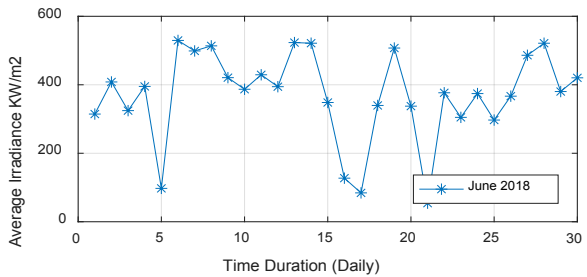

Figure 4. Daily average irradiance for the month of June 2018.

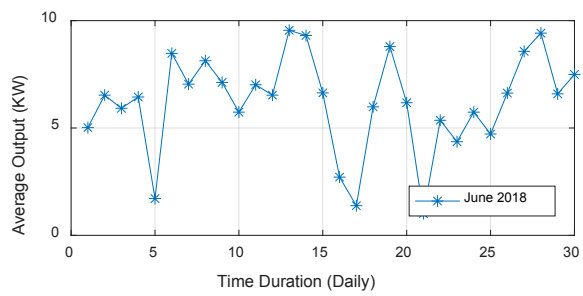

Figure 5. Daily average output in KW for the month of June 2018.

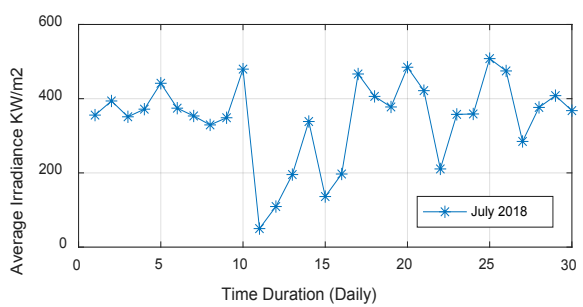

Figure 6. Daily average irradiance for the month of July 2018.

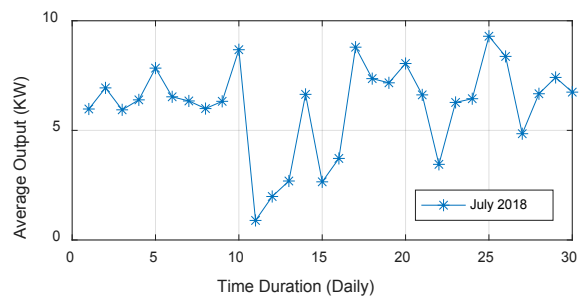

Figure 7. Daily average output in KW for the month of July 2018.

\subsection{Analysis for August, 2018}

In August, the monthly average output increased more than both previous months June and July, because of the higher irradiance level as shown in Figure 8 with mostly clear weather, relatively low humidity and increasing temperature. The average output of the month is $6.4 \mathrm{KW}$ as shown in Figure 9 with efficiency at $32 \%$ relatively higher than the month of July, because the average irradiance level increases with high average temperature $27.5^{\circ} \mathrm{C}$ and humidity at $62 \%$ and wind speed at $1.16 \mathrm{~km} / \mathrm{h}$.

\subsection{Analysis for September, 2018}

In September, the average temperature decreases as compared to that of August 
from $28^{\circ} \mathrm{C}$ to $20^{\circ} \mathrm{C}$ and the humidity level at $59 \%$. The average efficiency of the month stays at $32 \%$ at an average temperature of $19^{\circ} \mathrm{C}$. The module efficiency for this month varies drastically between $20 \%$ and $90 \%$ because of the dramatic changes in weather. The average irradiance and average output power of the month can be seen in Figure 10 and Figure 11.

\subsection{Analysis for October, 2018}

October proved to be the best result oriented month in terms of output power in Taiyuan where the temperature remains between $17^{\circ} \mathrm{C}$ and $12^{\circ} \mathrm{C}$ throughout the month and humidity level remains between $30 \%$ and $60 \%$ with average wind speed of $1.17 \mathrm{Km} / \mathrm{h}$ and average irradiance level remains constantly high for the whole month with just a few cloudy days which slightly lowered the average irradiance and output of plant.

Most of the days, the average output remained between $6 \mathrm{KW}$ and $9 \mathrm{KW}$ as shown in Figure 13 and irradiances level 350 to $580 \mathrm{KW} / \mathrm{m}^{2}$ as shown in Figure 12. Also, the measured average efficiency of $36 \%$ was recorded during this month.

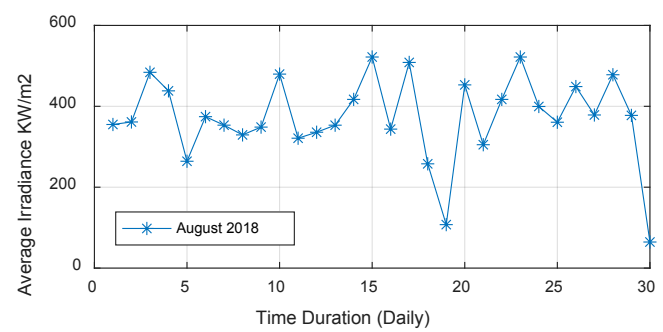

Figure 8. Daily average irradiance for the month of August 2018.

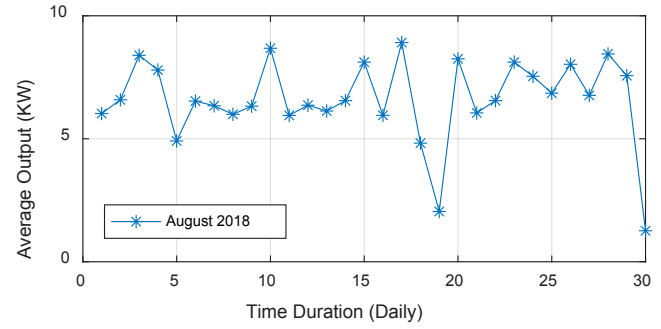

Figure 9. Daily average output in KW for the month of August 2018.

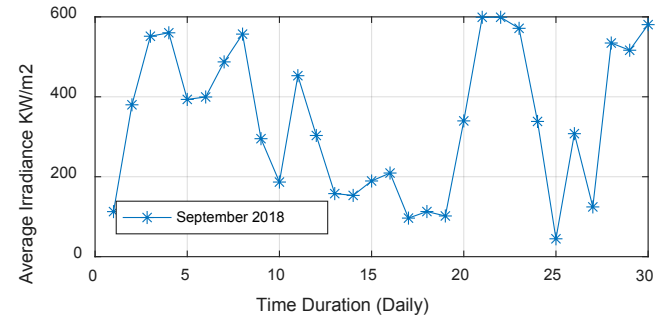

Figure 10. Daily average irradiance for the month of September 2018. 


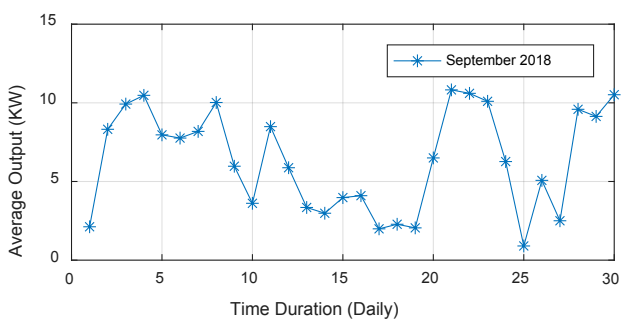

Figure 11. Daily average output in KW for the month of September 2018.

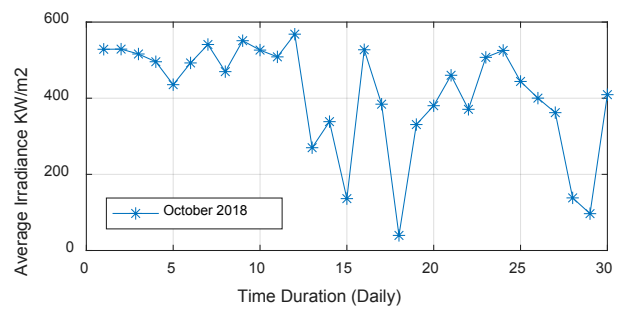

Figure 12. Daily average irradiance for the month of October 2018.

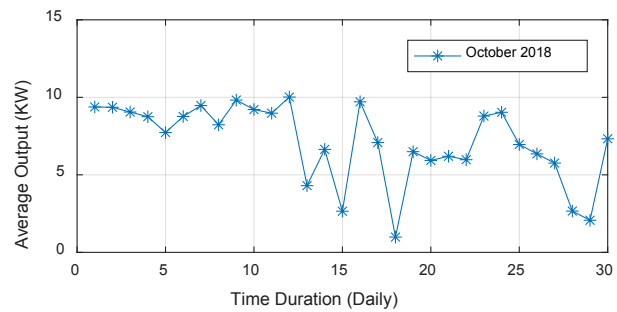

Figure 13. Daily average output in KW for the month of October 2018.

\subsection{Analysis for November, 2018}

In comparison to the previous months, the efficiency of the module in November decreases significantly to $28 \%$ because the temperature decreases gradually to a very low level of $2^{\circ} \mathrm{C}$ and high humidity of $90 \%$. Low temperature and less irradiance level significantly affect the output of the module. Foggy and cloudy conditions and the decrease in sun time to 9 hours a day during this month are the main factors which cause the irradiance level to decrease even under the clear sky, because of which the output power and efficiency tend to decrease as shown in Figure 14 and Figure 15.

\subsection{Analysis for December, 2018}

In December where the sky remains clear and low humidity level with a temperature between $0^{\circ} \mathrm{C}$ and $-10^{\circ} \mathrm{C}$ and the irradiance level remained less than 450 $\mathrm{KW} / \mathrm{m}^{2}$ as shown in Figure 16. The main reasons of less output in this month were the weaker irradiance because of low angle of the sun and also the short time of sun during this month which was 9 hours, that's why even under a clear sky and less humidity level the output power was comparatively less as shown in Figure 17. 


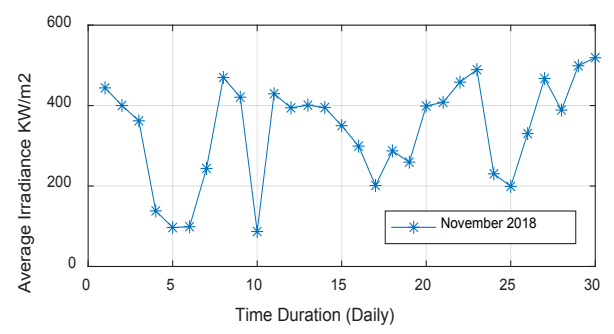

Figure 14. Daily average irradiance for the month of November 2018.

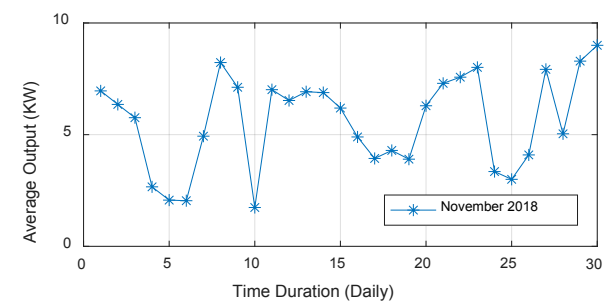

Figure 15. Daily average output in KW for the month of November 2018.

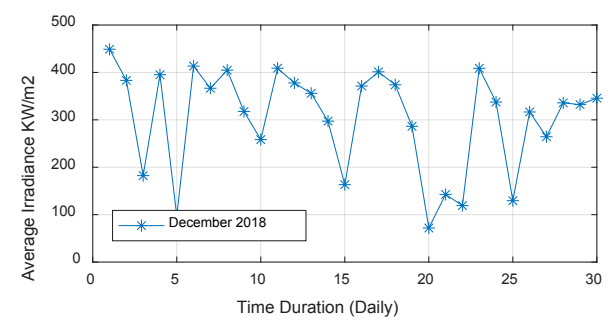

Figure 16. Daily average irradiance for the month of December 2018.

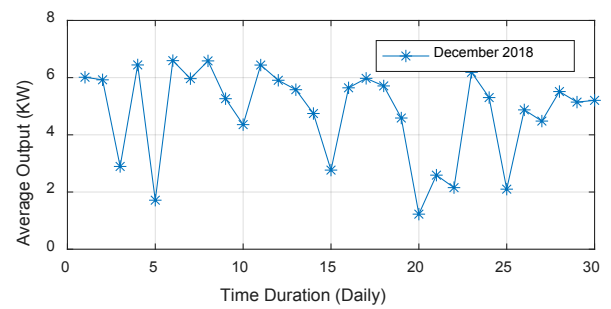

Figure 17. Daily average output in KW for the month of December 2018.

\subsection{Analysis for January, 2019}

January is the most less-efficient month with lower irradiance level and output power as shown in Figure 18 and Figure 19, because in January the sun time is shorter compared to the previous months and the weaker sunshine where irradiance level only remains between $250 \mathrm{KW} / \mathrm{m}^{2}$ and $430 \mathrm{KW} / \mathrm{m}^{2}$. Weather in January remains clear having no rain with very fewer clouds throughout the month but temperature mostly remains between -2 to -10 with the cold wind of $1 \mathrm{KM} / \mathrm{h}$. The efficiency level drops to $20 \%$ in January as can be seen in Figure 20. The main reason of less output is the short time of sun, weaker sunshine in winter days, also during the night, the temperature drops to almost -20 and 
module temperature remain less than the atmospheric temperature most of the time.

\section{Factors and Their Effects}

\subsection{Temperature}

The investigation results lead us to know that the output efficiency is significantly affected by the temperature. With the increasing temperature above $30^{\circ} \mathrm{C}$ a decline can be seen in the output efficiency as shown in Figure 20. Whereas, when the temperature is minimum or less than zero, a drastic deficiency can be seen in the output. A suitable temperature for Polycrystalline solar cells in the selected site for our investigation is between $10^{\circ} \mathrm{C}$ and $20^{\circ} \mathrm{C}$.

\subsection{Humidity}

The best suitable humidity level for the investigated solar cells recorded in this study is $40 \%$ average. With an increasing humidity level of more than $50 \%$ drastically decrease the output efficiency. As can be seen in Figure 21, the humidity level positively affects the efficiency by $5 \%$ when it decreases from $65 \%$ to $45 \%$. With humidity, less than $25 \%$ drastically decreased the efficiency of investigated solar cells mainly because of the temperature which was about $0^{\circ} \mathrm{C}$ or less. It has been found out in this investigation that low humidity with a temperature lower than $5^{\circ} \mathrm{C}$ is the worst climate condition for the Polycrystalline solar cells.

\subsection{Irradiance}

Irradiance is the most crucial factor for Polycrystalline or any solar cells. As can be seen in Figure 22, the efficiency is directly proportional to the irradiance level. The higher the irradiance level the higher the output efficiency, but with a higher irradiance, the temperature of solar cells increases which can result in the diffusion of solar cells.

\subsection{Wind Speed}

Wind speed in the selected site where this investigation is carried out has a minor effect on the output efficiency of Polycrystalline solar cells. Whereas, the wind directly blowing towards the solar face influences the solar module as it decreases the module temperature which consequently increases the efficiency. The spacing between the individual solar string along the wind direction affects the natural cooling of module temperature. The wind speed and efficiency are depicted in Figure 23.

\section{Conclusions}

The main goal of this investigative study was to assess the impact of weather effects on the performance of Polycrystalline solar cells. After analyzing eight months of data collected from a solar power plant installed at Taiyuan University of Technology, China, a recommendation can be made on the usage of Poly- 
crystalline solar cells that can serve as a guidance for future users who will be interested to use it as an alternative energy source.

From the results of this investigation, it can be concluded that, the main factors affecting the efficiency of Polycrystalline solar cells are found to be the temperature, humidity, and level of irradiance. With high temperature and high

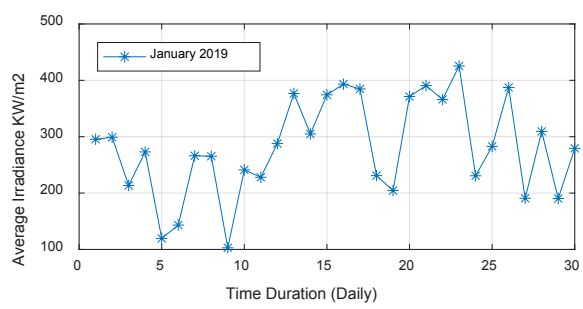

Figure 18. Daily average irradiance for the month of January 2019.

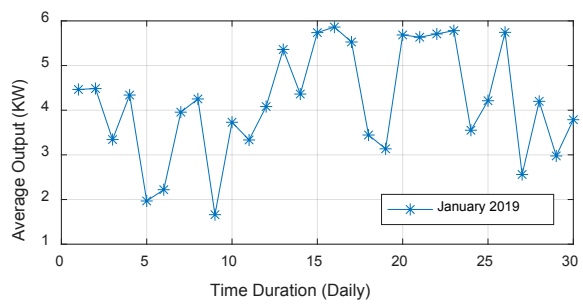

Figure 19. Daily average output in KW for the month of October 2018.
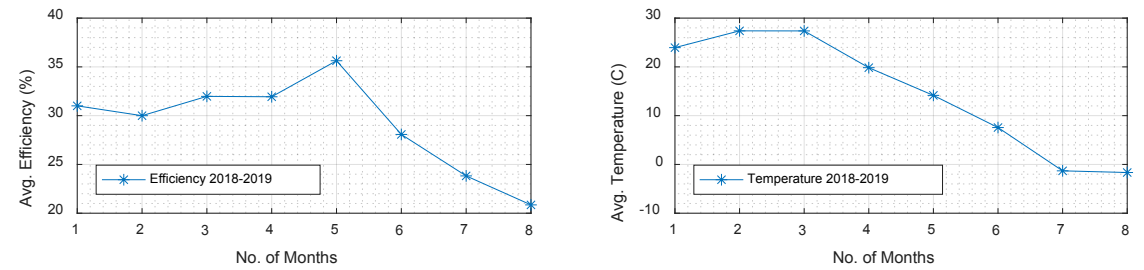

Figure 20. The effect of temperature on efficiency (monthly average).
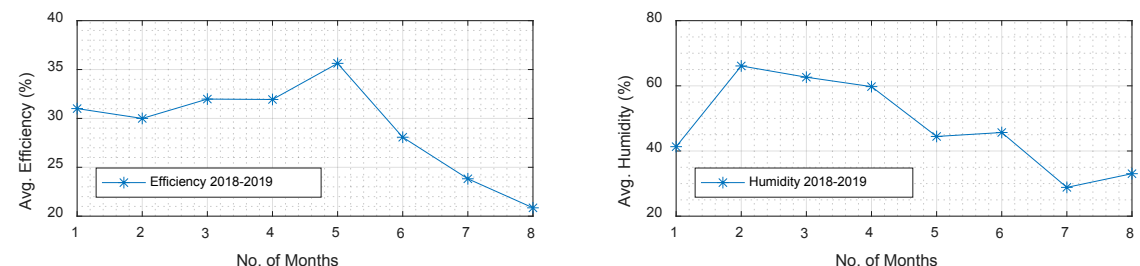

Figure 21. The effect of humidity on efficiency (monthly average).
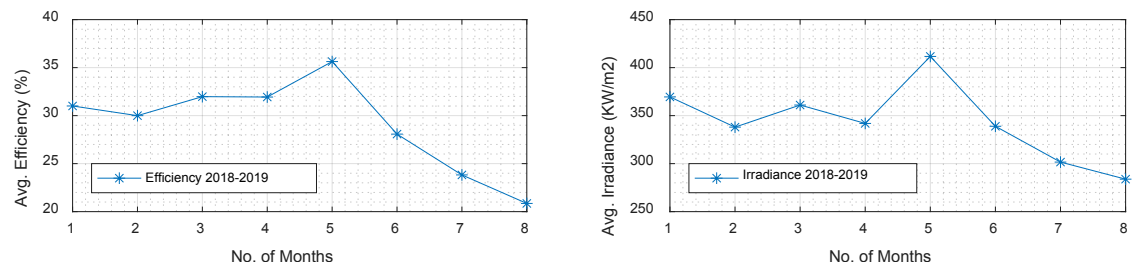

Figure 22. The effect of irradiance on efficiency (monthly average). 

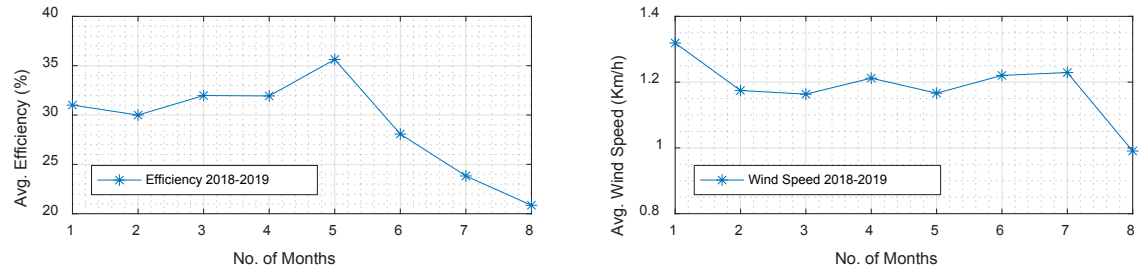

Figure 23. The effect of wind speed on efficiency (monthly average).

humidity, the efficiency of the solar module tends to decrease, whereas, with a high temperature and less humidity, the Polycrystalline solar cells found to be more efficient. Moreover, with low humidity and low temperature, the efficiency found to be minimum and with a low temperature and high humidity, the output power tends to decrease to minimum. Whereas the irradiance level has a direct impact on the solar cells, the output of Polycrystalline solar cells varies directly with the variation of irradiance level.

The climate conditions in China are very effective for solar energy, because weather conditions are very much predictable and the sun time is about 10 hours daily. In order to provide a complete guidance for the users and all other related beneficiaries of solar cells in China, a comparative research is in progress on different Solar modules i.e. Polycrystalline, Monocrystalline solar cells etc.

\section{Conflicts of Interest}

The authors declare no conflicts of interest regarding the publication of this paper.

\section{References}

[1] Ye, J.Y., Reindl, T., Aberle, A.G. and Walsh, T.M. (2014) Performance Degradation of Various PV Module Technologies in Tropical Singapore. IEEE Journal of Photovoltaics, 4, 1288-1294. https://doi.org/10.1109/JPHOTOV.2014.2338051

[2] Meral, M.E. and Dincer, F. (2011) A Review of the Factors Affecting Operation and Efficiency of Photovoltaic-Based Electricity Generation Systems. Renewable and Sustainable Energy Reviews, 15, 2176-2184. https://doi.org/10.1016/j.rser.2011.01.010

[3] Sastry, O.S., Saurabh, S., Shil, S.K., Pant, P.C., Kumar, R., Kumar, A. and Bandopadhyay, B. (2010) Performance Analysis of Field Exposed Single Crystalline Silicon Modules. Solar Energy Materials and Solar Cells, 94, 1463-1468. https://doi.org/10.1016/j.solmat.2010.03.035

[4] Müller, J, Fischer, J., Hünerbein, A., Deneke, H. and Macke, A. (2013) Using SEVIRI Radiances to Retrieve Cloud Optical Properties of Convective Cloud Systems. AIP Conference Proceedings, 1531, 468-471.

https://doi.org/10.1063/1.4804808

[5] Ramli, M.A., Prasetyono, E., Wicaksana, R.W., Windarko, N.A., Sedraoui, K. and Al-Turki, Y.A. (2016) On the Investigation of Photovoltaic Output Power Reduction Due to Dust Accumulation and Weather Conditions. Renewable Energy, 99, 836-844. https://doi.org/10.1016/j.renene.2016.07.063

[6] Albizzati, E.D., Rossetti, G.H. and Alfano, O.M. (1997) Measurements and Predic- 
tions of Solar Radiation Incident on Horizontal Surfaces at Santa Fe, Argentina ( $31^{\circ}$ 39'S, 6043'W). Renewable Energy, 11, 469-478.

https://doi.org/10.1016/S0960-1481(97)00017-7

[7] Amin, N., Lung, C.W. and Sopian, K. (2009) A Practical Field Study of Various Solar Cells on Their Performance in Malaysia. Renewable Energy, 34, 1939-1946. https://doi.org/10.1016/j.renene.2008.12.005

[8] Nfaoui, M. and El-Hami, K. (2018) Extracting the Maximum Energy from Solar Panels. Energy Reports, 4, 536-545. https://doi.org/10.1016/j.egyr.2018.05.002

[9] Guechi, A., Chegaar, M. and Merabet, A. (2011) The Effect of Water Vapor on the Performance of Solar Cells. Physics Procedia, 21, 108-114.

https://doi.org/10.1016/j.phpro.2011.10.016 